\title{
Role of Chromium Enriched Tobacco in the Occurrence of Oral Carcinogenesis
}

\section{IJCRR \\ Section: Healthcare \\ Sci. Journal Impact \\ Factor: 6.1 (2018) \\ ICV: 90.90 (2018) \\ (c) (i) (8) \\ Copyright@IJCRR}

\section{ABSTRACT}

Cancer is a disease of major concern grasping the entire globe. It is one of the diseases characterized by high rates of incidence and mortality. Among all the cancer types, oral cancer has a high occurrence in countries like India, where people are more inclined towards the use of tobacco either for smoking or for chewing purpose. Nicotianatabacum being a hyperaccumulator plant can thus accumulate high amount of heavy metals in its parts, mostly leaves. The carcinogenicity of tobacco may be linked to the high concentrations of metals present in it. The presence of chromium in the trivalent or $\mathrm{Cr}$ (III) form in the leaves of the tobacco plant is ignored assuming it to be non-toxic. However, smoking or chewing tobacco can lead to the conversion of $\mathrm{Cr}$ (III) to the toxic $\mathrm{Cr}(\mathrm{VI})$ as hypothesized in the current review. The paper in its current form discusses the process of aggregation of chromium in the above-ground parts of the tobacco plant. The rhizospheric factors that promote the metal uptake by the plant are also discussed. The notion that $\mathrm{Cr}$ in tobacco is harmless has been argued upon. The paper proposes the role of $\mathrm{Cr}$ enriched tobacco in causing oral cancer and predicts the probable underlying mechanism. It emphasizes on the need to regulate rhizospheric factors, to prevent the accumulation of high concentration of the toxic heavy metal in the biomass of the tobacco plant.

Key Words: Cancer, Chromium, Heavy metal, Mutation, Rhizosphere, Tobacco

\section{INTRODUCTION}

Cancer is one of the leading global diseases responsible for high incidence and mortality rates. In terms of the number of deaths, it lies second only to cardiovascular disease accounting for $16 \%$ of mortality (Fig.1). As per the 2018 GLOBOCAN statistics, one out of five males and one out of six females are found to suffer from cancer, while one out of eight males and one out of eleven females die of the disease. ${ }^{1}$ Cancer of the lip and oral cavity is the second most common cancer in India as far as the incidence (10.4\%) and mortality rates $(9.3 \%)$ are concerned. ${ }^{2}$ Oral cancer is caused due to addiction habits and Human Papilloma Virus (HPV). However, majority of oral cancer in India is caused due to consumption of tobacco products either in form of smoking or non-smoke forms and account for $80-90 \%$ of cases. ${ }^{3,4}$ Indian Council of Medical Research (ICMR) has reported that $30 \%$ of all cancers in India are mainly caused due to tobacco. Among the tobacco linked cancers, oral cancer is the most frequent type in India and is responsible for approximately $42 \%$ of deaths in males. ${ }^{5}$
Tobacco has been reported to contain high levels of metal possibly resulting in an increased risk of exposure of these toxic components to the smokers and consumers of various products of smokeless tobacco. The toxic effect of these carcinogenic metals present in tobacco depends on the dose and the time of exposure. These toxic metals and metalloids present in tobacco are poorly studied and the mechanism behind their toxicity remains unexplained.$^{6}$ Among several chemical compounds present in tobacco, 11 of these are metals or metalloids. An expert panel on tobacco regulation constituted by WHO prioritized four of the heavy metals like nickel, cadmium, arsenic, and lead in tobacco and tobacco smoke as of serious concern. ${ }^{7}$ The tobacco constituents are mostly related to several diseases especially cancer.

Chromium is a toxic heavy metal present in tobacco but its role in carcinogenesis is poorly understood and therefore ignored. The current review explains the probable role of hexavalent chromium generated from tobacco consumption and smoking in oral carcinogenesis. The authors have put

\section{Corresponding Author:}

Prof. Santosh Kumar Swain, Professor, Department of Otorhinolaryngology, IMS\&SUM Hospital, Siksha O Anusandhan (Deemed to be University), Kalinga Nagar, Bhubaneswar-751003, Odisha, India; Cell: +91-9556524887; Email:santoshswain@soa.ac.in

ISSN: 2231-2196 (Print) ISSN: 0975-5241 (Online)

Received: 12.06 .2020

Revised: 18.07.2020

Accepted: 20.08 .2020

Published: 22.09 .2020 
forward a hypothetical model predicting the possible pathway of $\mathrm{Cr}(\mathrm{VI})$ involvement in oral carcinogenesis.

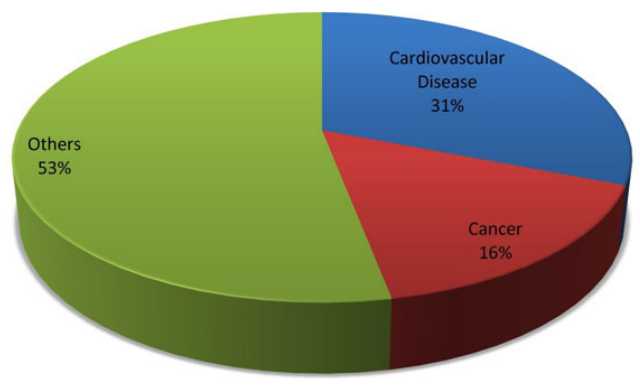

Figure 1: Two leading diseases with the highest global mortality rate.

\section{Chromium in oral carcinogenesis}

Chromium, unlike other toxic heavy metals, is available in several oxidation states, out of which, the trivalent or $\mathrm{Cr}$ (III) and the hexavalent or $\mathrm{Cr}(\mathrm{VI})$ are the two highly stable forms ${ }^{8} \mathrm{Cr}(\mathrm{VI})$ is considered to be a carcinogen because of its several toxic effects on the living biota including humans. ${ }^{9,10}$ Chromium remains a chief constituent of tobacco. It is mostly found in the trivalent form in tobacco products and therefore is not regarded as toxic. However, the inter-conversion of $\mathrm{Cr}$ in tobacco smoke and non-smoke form and its role in carcinogenesis has been poorly understood.

\section{Sources of $\mathrm{Cr}$ in the environment}

Cr mainly occurs from two sources - natural and anthropogenic (Fig.2). Cr occurs naturally over the earth crust in rocks, soil, water streams, and volcanic dust. It generally remains as $\mathrm{Cr}$ (III) bound to primary rocks and other metal oxides like iron. ${ }^{11}$ Anthropogenic sources are mostly responsible in increasing the toxic load of $\mathrm{Cr}(\mathrm{VI})$ in the environment and can be further categorized into direct and indirect sources. The direct sources include industrial operations like mining, leather tanning, chrome plating, wood preservation, and production of paints, pigments, dyes, paper, and pulp. ${ }^{8}$ Water treatment plants, Portland cement, dumping of wastes and effluents, incineration of wastes, coke ovens, and cooling towers are some of the indirect sources ofenvironmentalCr(VI). ${ }^{12}$ Dumping of $\mathrm{Cr}$ rich solid and liquid wastes mainly contribute towards environmental toxicity.

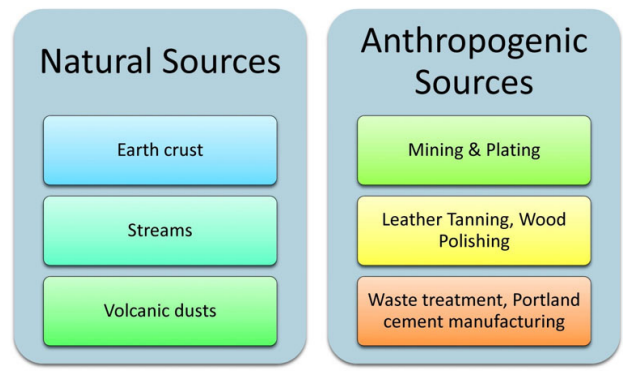

Figure 2: Sources of chromium $(\mathrm{Cr})$ in the environment.

\section{$\mathrm{Cr}(\mathrm{VI})$ and human carcinogenicity}

The chemical structure of $\mathrm{Cr}(\mathrm{VI})$ plays a major role in facilitating its entry into human cells and thereby causing toxic effects(Fig.3). Cr(VI) mostly exist in the form of oxyanion $\left(\mathrm{CrO}_{4}\right)$ which structurally resembles that of sulphate oxyanions $\left(\mathrm{SO}_{4}\right)$. This structural resemblance allows $\mathrm{Cr}(\mathrm{VI})$ to use sulphate transporters present on the cell surface to enter the cells. ${ }^{14} \mathrm{Cr}(\mathrm{VI})$ is mutagenic to human cells and is responsible for causing genotoxicity. It leads to the formation of DNA adducts which includes DNA-proteins crosslinks and DNA-aminoacids crosslinks ${ }^{15}$ which in turn inhibits DNA replication process. $\mathrm{Cr}(\mathrm{VI})$ also creates genomic instability by causing double-strand DNA breaks ${ }^{16}$. $\mathrm{Cr}(\mathrm{VI})$ causes epigenetic silencing, mutations, thereby leading to loss of mismatch repair mechanism ${ }^{16}$. The toxic form of the heavy metal induces chromosomal instability and abnormalities thereby causing DNA lesions ${ }^{17}$. Cr(VI) has been found to alter gene expression and actively induce the development of cancer through several mechanisms. It has also been found to actively participate in DNA methylation and gene silencing thereby leading to several types of cancer ${ }^{18}$. $\mathrm{Cr}(\mathrm{VI})$ is also believed to have a certain influence on microRNAs. The microRNAs play an active role in gene regulation and are often found to be dysregulated in $\mathrm{Cr}(\mathrm{VI})$ carcinogenesis thereby affecting important biological processes ${ }^{19,20}$.

\section{Chromium in Tobacco: Nicotianatabacum as a metal accumulator}

Plants can uptake essential elements from the soil and utilize them as nutrients. However, certain plants can aggregate high metal concentrations in their biomass and are referred to as hyperaccumulators ${ }^{12}$. Such plants are used to clean up soils contaminated with heavy metals by the process known as phytoremediation ${ }^{21}$. Similar metal accumulation ability by Nicotianatabacum plant makes it a viable option for metal removal from contaminated soils. However, such ability of the tobacco plant becomes a threat to health. Nicotianatabacum can uptake several heavy metals from the soil which includes cadmium, aluminium, arsenic, chromium, nickel, copper, zinc, lead and mercury. These metals are uptaken by the roots and then translocated and stored in the above-ground parts of the plant, mostly leaves. Cr is mostly up taken from the soil and translocated to aerial parts of the tobacco plant in its hexavalent state. The transport of $\mathrm{Cr}(\mathrm{VI})$ from roots to shoot is an active process and occurs through sulphate or phosphate channels ${ }^{22}$. Once $\mathrm{Cr}(\mathrm{VI})$ reaches the leaves, it gets reduced to $\mathrm{Cr}(\mathrm{III})$ by binding to specific ligands and sequestered into leaf vacuoles ${ }^{23}$ of the tobacco plant where it is stored as $\mathrm{Cr}(\mathrm{III})$.

\section{Chromium accumulation and factors governing its bioavailability for uptake}

Accumulation of $\mathrm{Cr}(\mathrm{VI})$ in hyperaccumulator plants like $\mathrm{Ni}$ cotianatabacumis highly dependent on several rhizospheric 
soil factors like redox potential, $\mathrm{pH}$, organic content, and availability of suitable microorganisms ${ }^{24}$.

The redox potential (Eh) of soil provides idea on the oxidation and reduction nature of the soil and plays a pivotal role in bioavailability and speciation of $\mathrm{Cr}(\mathrm{VI})$ in the soil. At high soil Eh values, generally, an oxidation reaction occurs ${ }^{25,26}$. Soils with high Eh values can cause the $\mathrm{Cr}$ (III) present in the soil to get oxidized to highly mobile $\mathrm{Cr}(\mathrm{VI})$, thereby increasing its availability in the soil for uptake by the plant.

Soil $\mathrm{pH}$ also is an important factor in metal availability to plants. Metals are highly soluble and mobile in acidic $\mathrm{pH}$ and are precipitated over alkaline soil conditions ${ }^{27}$. However, the same does not apply to $\mathrm{Cr}$ and its bioavailability under varied $\mathrm{pH}$ conditions depends on the form in which it is present in the soil. $\mathrm{Cr}(\mathrm{VI})$ mostly exists in the anionic form $\left(\mathrm{CrO}_{4}^{2-}\right.$ and $\left.\mathrm{HCrO}_{4}^{-1}\right)$ in the soil. Its bioavailability and mobility increases under high $\mathrm{pH}$ conditions and the reverse happen at low $\mathrm{pH}$. At high $\mathrm{pH}$, the hydroxyl ions increase providing the soil with a net negative charge and thereby decreasing sorption of $\mathrm{Cr}(\mathrm{VI}){ }^{28}$.

Soil organic matter content also plays a vital role in the movement and availability of $\mathrm{Cr}(\mathrm{VI})^{29}$. Presence of soil organic matter lowers the soil $\mathrm{pH}$ making it acidic and thus increasing $\mathrm{H}^{+}$ion concentrations. This positive charge of the soil helps in retention or adsorption of $\mathrm{Cr}(\mathrm{VI})$ to soil matrix ${ }^{30}$. Moreover, organic matter creates a reduced condition in the soil and also favours the growth of microorganisms. Therefore, $\mathrm{Cr}$ (VI) is reduced in two different ways catalysed in the presence of soil organic content. Firstly organic content of the soil creates reduced conditions that directly reduces $\mathrm{Cr}(\mathrm{VI})$ to $\mathrm{Cr}(\mathrm{III})^{31}$. Secondly, it favours microbial growth indirectly leading to reduction of $\mathrm{Cr}(\mathrm{VI})$ to $\mathrm{Cr}(\mathrm{III})$ as a result of biotic interaction between the microbes and the heavy metal ${ }^{32}$.

The rhizosphere soil due to its high nutrient concentration forms a favourable habitat for the growth of microorganisms. The microorganisms mostly bacteria have been found to play a major role in enhancing soil fertility and sustaining plant growth by processes such as mineralization, decomposition, nutrient immobilization, and nitrogen fixation ${ }^{33}$. As far as the biogeochemical activity of heavy metals in the plant-soil rhizosphere is concerned, microbes indeed play an influential role ${ }^{34,35}$. Several groups of microorganisms having the ability to reduce $\mathrm{Cr}(\mathrm{VI})$ to $\mathrm{Cr}(\mathrm{III})$ have been identified ${ }^{36}$. These include bacteria ${ }^{37}$, algae ${ }^{38}$, fungi ${ }^{39}$, and yeast ${ }^{40}$. Microbial reduction of $\mathrm{Cr}(\mathrm{VI})$ to $\mathrm{Cr}(\mathrm{III})$ highly relies on the microbial strain, concentration of chromium, $\mathrm{pH}$, and temperature of the soil ${ }^{41,42}$.

Soil conditions like high redox potential, high $\mathrm{pH}$, low organic content, and high soil temperature are the driving force for successful accumulation of $\mathrm{Cr}(\mathrm{VI})$ by tobacco plant and need to be regulated accordingly.

\section{$\mathrm{Cr}(\mathrm{VI})$ rich tobacco in oral cancer: A hypoth- esized model}

Chromium is a chief constituent in tobacco which may be attributed to the hyperaccumulation ability of the tobacco plant under favourable conditions. $\mathrm{Cr}$ is found in the trivalent form in tobacco and therefore not considered to be toxic by several researchers. The authors in the current review however have put forward contrasting views. The manuscript in its current form strongly advocates the probable involvement of $\mathrm{Cr}(\mathrm{VI})$ rich tobacco in oral cancer. A hypothetical model explaining the probable mechanism underlying oral carcinogenesis due to the presence of chromium in tobacco has been put forward.

The tobacco plant has been known to accumulate heavy metals like $\mathrm{Cr}$ in its aerial parts, mostly leaves. The leaves of the plant accumulate the heavy metal in its trivalent (non-toxic) form. Therefore, $\mathrm{Cr}(\mathrm{III})$ is not considered as a carcinogen in tobacco. However, there is always a chance that the nontoxic $\mathrm{Cr}(\mathrm{III})$ may get oxidized to the toxic $\mathrm{Cr}(\mathrm{VI})$ under favourable conditions thus promoting carcinogenesis. $\mathrm{Cr}$ (III) and $\mathrm{Cr}(\mathrm{VI})$ are the two most stable states of $\mathrm{Cr}$ that can interchange their oxidation states by undergoing redox reactions under conditions like metal content, presence of oxygen, high temperature, and moisture. Tobacco leaves in addition to $\mathrm{Cr}$ also contain manganese $(\mathrm{Mn})$ which further oxidizes the less toxic $\mathrm{Cr}(\mathrm{III})$ to the highly toxic $\mathrm{Cr}(\mathrm{VI})$. During smoking of tobacco, the $\mathrm{Cr}(\mathrm{III})$ present in it may get oxidized to $\mathrm{Cr}(\mathrm{VI})$ due to the combustion of tobacco that involves oxygen and high temperature. Moreover, tobacco smoke when inhaled through mouth or nose gets mixed up with moisture thereby also leading to the formation of $\mathrm{Cr}(\mathrm{VI})$. $\mathrm{Cr}(\mathrm{VI})$ toxicity not only spreads from tobacco smoke but also smokeless forms. Tobacco, when taken in chewable form, gets in contact with oxygen and moisture thereby converting the elemental manganese present in it into $\mathrm{MnO}_{2}$, that catalyses the oxidation of $\mathrm{Cr}$ (III) to $\mathrm{Cr}(\mathrm{VI})$ (Fig.3).

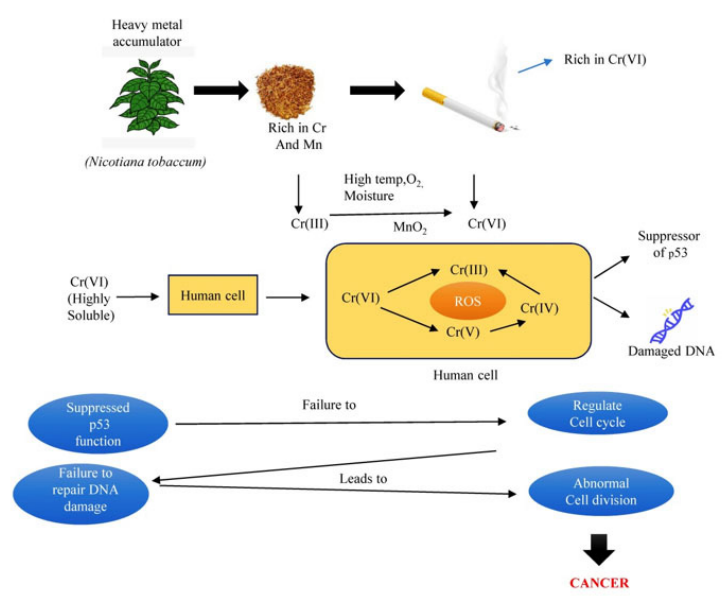

Figure 3: Mechanism underlying role of chromium enriched tobacco in causing oral cancer 
The oral cavity being the first point of contact of both smoking and non-smoking form of tobacco products is hence more exposed to $\mathrm{Cr}(\mathrm{VI})$ and most probably its toxic impacts like the occurrence of oral cancer. $\mathrm{Cr}(\mathrm{VI})$ being highly mobile and permeable easily passes through the human cell membrane. $\mathrm{Cr}(\mathrm{VI})$ generated from cigarette smoke or chewing of tobacco can easily get absorbed into the squamous epithelial cells present in the internal surface of the oral cavity. Once $\mathrm{Cr}(\mathrm{VI})$ enters into the cells, it undergoes detoxification. $\mathrm{Cr}(\mathrm{VI})$ either gets reduced to $\mathrm{Cr}(\mathrm{III})$ directly or indirectly in a stepwise manner. In the indirect reduction process $\mathrm{Cr}(\mathrm{VI})$ gets converted to $\mathrm{Cr}(\mathrm{III})$ via several intermediates like $\mathrm{Cr}(\mathrm{V})$ and $\mathrm{Cr}(\mathrm{IV})$. During the reduction, the different species of chromium produce intracellular reactive oxygen species (ROS). Chemical compounds present in the cells like ascorbic acid and glutathione act as ROS scavengers thereby reducing $\mathrm{Cr}(\mathrm{VI})$ to $\mathrm{Cr}(\mathrm{III})$ and in the process lead to the production of free radicals (hydroxyl radicals) ${ }^{43}$. Production of hydroxyl radicals inside the cells occurs in the presence of $\mathrm{H}_{2} \mathrm{O}_{2}$ through a Fenton-like reaction ${ }^{44}$. ROS in the form of hydroxyl radicals can activate various pathways like apoptosis ${ }^{45}$. $\mathrm{Cr}(\mathrm{VI})$ reduction inside the cells can also directly cause damage to the DNA by interacting with the proteins, amino acids, and even the DNA directly leading to single or doublestrand breakage ${ }^{46}$. $\mathrm{Cr}(\mathrm{VI})$ after reduction to $\mathrm{Cr}(\mathrm{III})$ can form bulky binary and ternary DNA adducts, thereby causing severe damage due to mutations ${ }^{47}$.

$\mathrm{Cr}(\mathrm{VI})$ induced oxidative damage mostly occurs to the DNA of $\mathrm{p}^{53}$ gene $\mathrm{H}^{48}$ present in the oral squamous cells thereby affecting the gene function. Being a tumour suppressor gene, $\mathrm{p}^{53}$ works as a control centre of the cell and regulates the activity of several genes under stress conditions and also is involved in DNA repair. Damage to this gene leads to failure of repair mechanism in DNA of the oral epithelial cells, thereby resulting in mutations, uncontrolled cell division and finally cancer of the oral cavity.

\section{CONCLUSION}

Tobacco consumption remains a significant threat to public health around the world and smoking-related diseases are considered the world's most preventable cause of death.

Consumption of tobacco causes a significant threat to public health. Tobacco-related diseases are linked to the world's most prevalent cause of death. Tobacco has several carcinogens. Chromium has a strong link with the carcinogenesis of oral cancer.Cr(VI) is a toxic heavy metal that arises from several anthropogenic activities. Nicotianatabacum is a plant hyperaccumulator that can easily accumulate heavy metals like $\mathrm{Cr}(\mathrm{VI})$ in large quantities from contaminated soil and water bodies. This is the main reason behind the presence of the toxic heavy metal in tobacco and tobacco products.
Being a major component of tobacco, $\mathrm{Cr}(\mathrm{VI})$ has all the possibility of causing oral cancer by bringing about DNA mutations in the $\mathrm{p}^{53}$ and other linked genes. The author(s) hereby advises preventing the accumulation of the toxic $\mathrm{Cr}(\mathrm{VI})$ in tobacco plant that is meant for commercial purposes to prevent the risk of oral carcinogenesis. This could be achieved by appropriately regulating the rhizospheric factors governing its uptake by the tobacco plant.

\section{REFERENCES}

1. The L. GLOBOCAN 2018: counting the toll of cancer. Lancet (London, England). 2018;392(10152):985.

2. World Health Organization.Global Health Observatory. Geneva: World Health Organization; 2018. Available from http://gco. iarc.fr/ [accessed January 18, 2020].

3. NCRP - Consolidated Report of Hospital-Based Cancer Registries 2007-2011, National Cancer Registry Programme (Indian Council of Medical Research), Bangalore, 2013.

4. Prasad JB, Dhar M. Projections of the burden of cancers: A new approach for measuring incidence cases for India and its statesTill 2025. J. Cancer policy. 2018;16:57-62.

5. Salvi S, Kumar GA, Dhaliwal RS, Paulson K, Agrawal A, Koul PA, Mahesh PA, Nair S, Singh V, Aggarwal AN, Christopher DJ. The burden of chronic respiratory diseases and their heterogeneity across the states of India: the Global Burden of Disease Study 1990-2016. Lancet Glob Health. 2018;6(12):e1363-74.

6. Fowles J, Dybing E. Application of toxicological risk assessment principles to the chemical constituents of cigarette smoke. Tob. Control. 2003;12(4):424-30.

7. WHO, Report on the scientific basis of tobacco product regulation: fourth report of a WHO study group, in WHO study group on tobacco product regulation (WHO Technical Report Series)2012, World Health Organisation: Geneva. p. 83.

8. Shi J, Zhang B, Qiu R, Lai C, Jiang Y, He C, Guo J. Microbial chromate reduction coupled to anaerobic oxidation of elemental sulfur or zerovalent iron. Environ.Sci. 2019;53(6):3198-207.

9. Mohanty M, Patra HK. Attenuation of chromium toxicity by bioremediation technology. In Rev Environ Contam T. 2011; 210:1-34. Springer, New York, NY.

10. Zhang B, Wang Z, Shi J, Dong H. Sulfur-based mixotrophic bioreduction for efficient removal of chromium (VI) in groundwater. GeochimicaetCosmochimicaActa. 2020;268:296-309.

11. Quentin C, Ettler V, Garnier J, Šebek O. Sources and extractibility of chromium and nickel in soil profiles developed on Czech serpentinites. C R Geosci. 2008;340(12):872-82.

12. Das PK, Das BP, Dash P. Role of Plant Species as Hyper-Accumulators in the Decontamination of Hexavalent Chromium Contaminated Soil. IJEP. 2018;38(12): 1016 - 1024.

13. Salnikow K, Zhitkovich A. Genetic and epigenetic mechanisms in metal carcinogenesis and cocarcinogenesis: nickel, arsenic, and chromium. Chem. Res. Toxicol. 2008 Jan;21(1):28-44.

14. Salnikow K, Zhitkovich A. Genetic and epigenetic mechanisms in metal carcinogenesis and cocarcinogenesis: nickel, arsenic, and chromium. Chemical research in toxicology. 2008 Jan 21;21(1):28-44.

15. Holmes AL, Wise SS, Wise Sr JP. Carcinogenicity of hexavalent chromium.Indian J Med Res. 2008.

16. Sun H, Zhou X, Chen H, Li Q, Costa M. Modulation of histone methylation and MLH1 gene silencing by hexavalent chromium. TOXICOL APPL PHARM. 2009;237(3):258-66. 
17. Mishra S, Bharagava RN. Toxic and genotoxic effects of hexavalent chromium in the environment and its bioremediation strategies. J ENVIRON SCI HEAL C. 2016;34(1):1-32.

18. Hu G, Li P, Li Y, Wang T, Gao X, Zhang W, Jia G. Methylation levels of P16 and TP53 that are involved in DNA strand breakage of $16 \mathrm{HBE}$ cells treated by hexavalent chromium. Toxicol. Lett. 2016;249:15-21.

19. He J, Qian X, Carpenter R, Xu Q, Wang L, Qi Y, Wang ZX, Liu LZ, Jiang BH. Repression of miR-143 Mediates Cr (VI)Induced Tumor Angiogenesis via IGF-IR/IRS1/ERK/IL-8 Pathway.Toxicological Sciences. 2013 Jul 1;134(1):26-38.

20. Chandra S, Pandey A, Chowdhuri DK. MiRNA profiling provides insights on adverse effects of $\mathrm{Cr}$ (VI) in the midgut tissues of Drosophila melanogaster. J. Hazard. Mater. 2015;283:558-67.

21. Das PK. Phytoremediation and nanoremediation: emerging techniques for treatment of acid mine drainage water. Def. Lif. Sci. J.2018;3(2):190-6.

22. Cervantes C, Campos-García J, Devars S, Gutiérrez-Corona F, Loza-Tavera H, Torres-Guzmán JC, Moreno-Sánchez R. Interactions of chromium with microorganisms and plants. FEMS Microbiol. Rev. 2001;25(3):335-47.

23. Shahid M, Austruy A, Echevarria G, Arshad M, Sanaullah M, Aslam M, Nadeem M, Nasim W, Dumat C. EDTA-enhanced phytoremediation of heavy metals: a review. SOIL SEDIMENT CONTAM. 2014;23(4):389-416.

24. Taghipour M, Jalali M. Influence of organic acids on the kinetic release of chromium in soil contaminated with leather factory waste in the presence of some adsorbents. Chemosphere. 2016; $155: 395-404$.

25. Frohne T, Diaz-Bone RA, Du Laing G, Rinklebe J. Impact of systematic change of redox potential on the leaching of $\mathrm{Ba}, \mathrm{Cr}$, $\mathrm{Sr}$, and V from a riverine soil into the water. J. Soils Sediments. 2015;15(3):623-33.

26. Shaheen SM, Rinklebe J. Geochemical fractions of chromium, copper, and zinc and their vertical distribution in floodplain soil profiles along the Central Elbe River, Germany. Geoderma. 2014;228:142-59.

27. Shahid M, Dumat C, Aslam M, Pinelli E. Assessment of lead speciation by organic ligands using speciation models. Chem Spec Bioavailab. 2012;24(4):248-52.

28. Dias-Ferreira C, Kirkelund GM, OttosenLM.Ammonium citrate as an enhancement for electrodialytic soil remediation and investigation of soil solution during the process.Chemosphere. 2015;119:889-95.

29. Shahid M, Xiong T, Castrec-Rouelle M, Leveque T, Dumat C. Water extraction kinetics of metals, arsenic and dissolved organic carbon from industrially contaminated poplar leaves. J. Environ. Sci. 2013;25(12):2451-9.

30. Choppala G, Kunhikrishnan A, Seshadri B, Park JH, Bush R, Bolan N. Comparative sorption of chromium species as influenced by $\mathrm{pH}$, surface charge and organic matter content in contaminated soils. J. Geochem. Explore. 2018;184:255-60.

31. Ashraf A, Bibi I, Niazi NK, Ok YS, Murtaza G, Shahid M, Kunhikrishnan A, Li D, Mahmood T. Chromium (VI) sorption efficiency of acid-activated banana peel over organomontmorillonite in aqueous solutions. Int J PHYTOREMEDIAT.2017;19(7):605-13
32. Banks MK, Schwab AP, Henderson C. Leaching and reduction of chromium in the soil as affected by soil organic content and plants. Chemosphere. 2006;62(2):255-64.

33. Desai C, Parikh RY, Vaishnav T, Shouche YS, Madamwar D. Tracking the influence of long-term chromium pollution on soil bacterial community structures by comparative analyses of $16 \mathrm{~S}$ rRNA gene phylotypes. Res. Microbiol. 2009;160(1):1-9.

34. Ahemad M. Enhancing phytoremediation of chromiumstressed soils through plant-growth-promoting bacteria. JGEB.2015;13(1):51-8.

35. Ahmad I, Akhtar MJ, Asghar HN, Ghafoor U, Shahid M. Differential effects of plant growth-promoting rhizobacteria on maize growth and cadmium uptake.J. Plant Growth Regul.2016;35(2):303-15.

36. Maqbool Z, Asghar HN, Shahzad T, Hussain S, Riaz M, Ali S, Arif MS, Maqsood M. Isolating, screening and applying chromium reducing bacteria to promote growth and yield of okra (Hibiscus esculentus L.) in chromium contaminated soils. Ecotoxicol. Environ. Saf. 2015;114:343-9.

37. Kafilzadeh F, Saberifard S. Isolation and identification of chromium (VI)-resistant bacteria from Soltan Abad river sediments (Shiraz-Iran). Jundishapur J Health Sci. 2016;8(1):e33576.

38. de Souza FB, de Lima Brand ao H, Hackbarth FV, de Souza AAU, Boaventura RA, de Souza SMGU, Vilar VJ. Marine macro-alga Sargassumcymosum as the electron donor for hexavalent chromium reduction to trivalent state in aqueous solutions. Chem. Eng. J. 2016;283: 903e910.

39. Sivakumar D. Biosorption of hexavalent chromium in a tannery industry wastewater using fungi species. GJESM. 2016;2(2):105.

40. Ksheminska H, Honchar T, Gayda G, Gonchar M. Extra-cellular chromate-reducing activity of the yeast cultures. Open Life Sci. 2006;1(1):137-49.

41. Joutey NT, Sayel H, Bahafid W, El Ghachtouli N. Mechanisms of hexavalent chromium resistance and removal by microorganisms. Rev Environ Contam T. 2015; 233:45-69.

42. Nguema PF, Luo Z. Aerobic chromium (VI) reduction by chromium-resistant bacteria isolated from activated sludge. Ann. Microbiol. 2012;62(1):41-7.

43. Chen QY, DesMarais T, Costa M. Metals and mechanisms of carcinogenesis.ANNU REV PHARMACOL. 2019;59:537-54.

44. Sun H, Brocato J, Costa M. Oral chromium exposure and toxicity. Curr. Environ. Health Rep. 2015;2(3):295-303.

45. Wise JT, Wang L, Xu J, Zhang Z, Shi X. Oxidative stress of $\mathrm{Cr}$ (III) and carcinogenesis.InThe Nutritional Biochemistry of Chromium (III) 2019; pp. 323-340

46. DeLoughery Z, Luczak MW, Ortega-Atienza S, Zhitkovich A. DNA double-strand breaks by $\mathrm{Cr}$ (VI) are targeted to euchromatin and cause ATR-dependent phosphorylation of histone H2AX and its ubiquitination. Tox Sci. 2015;143(1):54-63.

47. Quievryn G, Peterson E, Messer J, Zhitkovich A. Genotoxicity and mutagenicity of chromium (VI)/ascorbate-generated DNA adducts in human and bacterial cells. BIOCHEMISTRY-US. 2003;42(4):1062-70.

48. Arakawa H, Weng MW, Chen WC, Tang MS. Chromium (VI) induces both bulky DNA adducts and oxidative DNA damage at adenines and guanines in the p53 gene of human lung cells. Carcinogenesis. 2012;33(10):1993-2000. 